\title{
Effects of Intermittent Exercise during Initial Rainbow Trout Oncorhynchus mykiss Rearing in Tanks Containing Vertically-Suspended Environmental Enrichment
}

\author{
Benj Morris, Jill M. Voorhees*, Nathan Huysman, Eric Krebs and Michael E. Barnes \\ South Dakota Department of Game, Fish and Parks, McNenny State Fish Hatchery, 19619 Trout Loop, Spearfish, South Dakota 57783, USA
}

${ }^{\star}$ Corresponding author: Jill M. Voorhees, South Dakota Department of Game, Fish and Parks, McNenny State Fish Hatchery, Spearfish, South Dakota, USA; Tel: 6056426920; Fax:6056426921; Email: jill.voorhees@state.sd.us

Received: September 09, 2020; Accepted: September 11, 2020; Published: September 26, 2020

\begin{abstract}
This study evaluated the effect of an exercise routine on the hatchery rearing performance of juvenile rainbow trout (Oncorhynchus mykiss) reared in circular tanks containing vertically-suspended environmental enrichment. This experiment occurred in two sequential trials, with fish remaining in the same treatment group in each trial. The first trial began upon initial feeding and lasted for 47 days with velocities in the exercised tanks alternated biweekly between $5 \mathrm{~cm} \mathrm{~s}^{-1}$ and $8 \mathrm{~cm} \mathrm{~s}^{-1}$. The second trial began the day after the first trial ended and lasted for 98 days, with velocities in the exercised tanks alternating between $5 \mathrm{~cm} \mathrm{~s}^{-1}$ and $11 \mathrm{~cm} \mathrm{~s}^{-1}$. Velocities in the unexercised tanks stayed constant at $5 \mathrm{~cm} \mathrm{~s}^{-1}$ throughout the study. No significant differences in final tank weight, gain, percent gain, individual weight, individual length, feed conversion ratio, specific growth rate, or condition factor were found between the two treatments in either trial. These results indicate that an intermittent exercise regime does not improve the hatchery rearing performance of juvenile rainbow trout grown in circular tanks with vertically-suspended enrichment.
\end{abstract}

Keywords: Exercise, Structure, Enrichment, Rainbow trout, Oncorhynchus mykiss

\section{Introduction}

Modifications to fish rearing units to encourage natural behaviors or mimic natural habitats have been studied with many different fish species [1-4]. Different forms of environmental enrichment have been shown to increase growth and post-stocking survival of fish raised in hatcheries [5]. Environmental enrichment research has particularly focused on salmonids during hatchery rearing [6-10].

Occupational enrichment is a category of environmental enrichment including exercise [5]. Fish are typically forced to exercise by increasing water velocities [9-11], which has generally been associated with increased fish growth. However, when fish are over-exercised, fatigue and reduced rearing performance can occur $[12,13]$. Most exercise studies start with relatively larger and older salmonids [2,3,9,14-16]. Beginning an exercise routine at initial feeding has not occurred.

Physical structure has been added to fish rearing tanks as a form of environmental enrichment [17-24]. Vertically-suspended structures were developed to add enrichment but still maintain circular tank hydraulic self-cleaning. Kientz and Barnes [25] and Kientz et al. [26] reported an increase in rainbow trout (Oncorhynchus mykiss) growth using suspended aluminum rods and suspended strings of plastic spheres. Positive results using a variety of vertically-suspended structures with a variety of salmonid species have been reported [27-33].

Voorhees et al. [16] evaluated the combination of verticallysuspended structure and an exercise routine during juvenile rainbow trout rearing and found no significant interaction between structure and exercise. Given the lack of paucity of information on exercise in conjunction with vertically-suspended structure, and exercise in general with small salmonids, the objective of this study was to evaluate the effects of an exercise routine, beginning at initial feeding, on the rearing performance of rainbow trout reared in circular tanks containing vertically-suspended environmental enrichment.

\section{Methods}

This experiment was conducted at McNenny State Fish Hatchery, rural Spearfish, South Dakota, USA, using degassed and aerated wellwater (constant temperature $11^{\circ} \mathrm{C}$; total hardness as $\mathrm{CaCO}_{3}, 360 \mathrm{mg}$ $\mathrm{L}^{-1}$; alkalinity as $\mathrm{CaCO}_{3}, 210 \mathrm{mg} \mathrm{L}^{-1} ; \mathrm{pH}, 7.6$; total dissolved solids, 390 $\mathrm{mg} \mathrm{L}^{-1}$ ) using 2,000-L circular tanks (1.8 $\mathrm{m}$ diameter x $0.6 \mathrm{~m}$ deep; 0.4 $\mathrm{m}$ water depth). This experiment used Arlee strain rainbow trout in two sequential trials.

All tanks contained vertically-suspended environmental enrichment, which consisted of an array of four suspended aluminum angles (2.5-cm wide on each angle side $\mathrm{x} 57.15-\mathrm{cm}$ long) [27] suspended from a corrugated plastic cover [34]. The angles were placed so the peak of the angle faced into the water current.

Fish were fed every 15 minutes during daylight hours using automatic feeders. Feeding rates were determined by the hatchery constant method [35], with an expected feed conversion ratio of 1.1. Total feed fed was $116.7 \mathrm{~kg}$ per tank throughout the entire experiment. 
Benj Morris (2020) Effects of Intermittent Exercise during Initial Rainbow Trout Oncorhynchus mykiss Rearing in Tanks Containing VerticallySuspended Environmental Enrichment

The experimental design for each trial was similar, with treatments being either unexercised (control) or exercise. Velocities in the control tanks were maintained at $5 \mathrm{~cm} \mathrm{~s}^{-1}$, the minimum velocity required for hydraulic self-cleaning. Exercise occurred by changing the angle of the incoming water (spray bar) to increase in-tank water velocities; incoming water flows were not changed. The exercise regime was alternating every 84 hours ( 3.5 days) between velocities of $5 \mathrm{~cm} \mathrm{~s}^{-1}$ and higher velocities of 8 to $11 \mathrm{~cm} \mathrm{~s}^{-1}$ depending on the trial. The exercise regime started after one week of acclimation to the lower velocity of 5 $\mathrm{cm} \mathrm{s}^{-1}$. Velocities were measured using a flowmeter (JDC Electronics Flowatch Flowmeter, JDC, Yverdon-les-Bains, Switzerland), with all readings taken directly across from the incoming water spray bar approximately $20 \mathrm{~cm}$ deep (halfway from water surface).

The first trial began on January 14, 2020 and lasted until March 2, 2020, for a total of 47 days. Each of eight tanks received $1.2 \mathrm{~kg}$ (approximately 6,600 fish) of trout (individual mean \pm SE, weight $=$ $0.2 \pm 0.0 \mathrm{~g}$, total length $26.8 \pm 0.4 \mathrm{~mm}, n=30$ ). Feeding rates were projected at $0.08 \mathrm{~cm} \mathrm{day}^{-1}$, a rate at or slightly above satiation. Fish were fed \#1 granules (Fry, Skretting USA, Tooele, Utah, USA) until February 4, when feed was switched to \#2 granules (Fry, Skretting USA, Tooele, Utah, USA). Four tanks received the control velocity and four tanks received the exercise regime $(n=4)$. The higher velocity used in the exercise regime was $8 \mathrm{~cm} \mathrm{~s}^{-1}$. At the end of the trial, total tank weight was obtained by weighing all fish in each tank to the nearest $0.1 \mathrm{~kg}$. In addition, ten individual fish from each tank were weighed to the nearest $0.1 \mathrm{~g}$ and total length measured to the nearest $1.0 \mathrm{~mm}$.

The second trial used the fish from the first trial and began on March 3, 2020, immediately after cessation of the first trial. The second trial lasted for 98 days until June 9, 2020, with the trout from the first trial subjected to the same treatment (control or exercised). Fish in the control treatment for the first trial were pooled (combined into one tank) and split into seven tanks, with each tank receiving $9.1 \mathrm{~kg}$ (approximately 3,600 fish). Initial mean \pm SE weights and total lengths were $2.5 \pm 0.1 \mathrm{~g}$ and $61 \pm 1 \mathrm{~mm}(n=40)$ respectively. The exercised fish from the first trial were also pooled and split into seven tanks, with each tank receiving $9.3 \mathrm{~kg}$ ( mean $\pm \mathrm{SE}$, weight $=2.7 \pm 0.1 \mathrm{~g}$, total length $61 \pm 1 \mathrm{~mm}, n=40$ ). Feeding rates were based on a projected growth of $0.075 \mathrm{~cm} \mathrm{day}^{-1}$. Fish were fed $\# 2$ granules (Fry, Skretting USA, Tooele, Utah, USA) until March 26, when the fish received 1.5 $\mathrm{mm}$ extruded floating pellets (Protec Trout, Skretting USA, Tooele, Utah, USA). The higher velocity used in the exercise regime was 11 $\mathrm{cm} \mathrm{s}^{-1}$. At the end of the trial, total tank and individual fish data was recorded as in the first trial.

The following formulas were used:

$$
\begin{aligned}
& \text { Gain = end weight }- \text { start weight } \\
& \text { Gain }(\%)=100 * \frac{\text { gain }}{\text { start weight }} \\
& \text { Feed conversion ratio }(\mathrm{FCR})=\frac{\text { food fed }}{\text { gain }} \\
& \text { Specific growth rate }(\mathrm{SGR})=100 * \frac{\ln \text { (end weight) }-\ln (\text { start weight) }}{\text { number of days }} \\
& \text { Condition factor }(\mathrm{K})=10^{5} * \frac{\text { fish weight }}{\text { fish length }^{3}}
\end{aligned}
$$

Data were analyzed using SPSS (24.0) statistical program (IBM Corporation, Armonk, New York, USA). T-tests were used with significance was predetermined at $\mathrm{p}<0.05$. This experiment was carried out within the American Fisheries Society "Guidelines for the Use of Fishes in Research" [36] and within the guidelines of the Aquatics Section Research Ethics Committee of the South Dakota Department of Game, Fish and Parks, USA.

\section{Results}

In both trials, no significant differences were found in final tank weight, gain, percent gain, feed conversion ratio, or percent mortality (Table 1). In the first trial, mean feed conversion ratios were relatively low at 0.75 in the control and 0.77 in those tanks of fish that were exercised. Feed conversion ratios were higher in the second trial and nearly identical between the groups at 1.12 in the control and 1.11 in the exercised treatment. Overall feed conversion for both trials combined was identical between the control and exercised groups. Mortality was relatively low and did not exceed $1.2 \%$ in either trial.

Individual total length, weight, specific growth rate, and condition factor were also not significantly different between the two groups in either trial (Table 2). Specific growth rate decreased from 5.59 and 5.73 in the control and exercised groups in the first trial respectively, to 2.81 and 2.70 in the second trial.

Table 1: Mean $\left( \pm\right.$ SE) final tank weight, gain, percent gain, feed conversion ratio $\left(F^{2}{ }^{a}\right)$, and percent mortality of rainbow trout reared with or without exercise.

\begin{tabular}{|l|l|l|l|}
\hline & & Unexercised & Exercised \\
\hline \multirow{5}{*}{ Trial 1 } & $n$ & 4 & 4 \\
\cline { 2 - 4 } & Initial weight $(\mathrm{kg})$ & 1.2 & 1.2 \\
\cline { 2 - 4 } & Final weight $(\mathrm{kg})$ & $16.0 \pm 0.8$ & $16.3 \pm 0.3$ \\
\cline { 2 - 4 } & Gain $(\mathrm{kg})$ & $14.7 \pm 0.8$ & $15.0 \pm 0.3$ \\
\cline { 2 - 4 } & Gain $(\%)$ & $1,207 \pm 64$ & $1,232 \pm 22$ \\
\cline { 2 - 4 } & FCR & $0.75 \pm 0.04$ & $0.77 \pm 0.01$ \\
\cline { 2 - 4 } & Mortality $(\%)$ & $1.2 \pm 0.3$ & $1.0 \pm 0.1$ \\
\hline \multirow{5}{*}{ Trial 2 } & n & 7 & 7 \\
\cline { 2 - 4 } & Initial weight $(\mathrm{kg})$ & 9.1 & $116.7 \pm 1.9$ \\
\cline { 2 - 4 } & Final weight $(\mathrm{kg})$ & $118.3 \pm 2.6$ & $107.6 \pm 1.9$ \\
\cline { 2 - 4 } & Gain $(\mathrm{kg})$ & $109.2 \pm 2.6$ & $1,183 \pm 21$ \\
\cline { 2 - 4 } & Gain $(\%)$ & $1,200 \pm 28$ & $0.11 \pm 0.02$ \\
\cline { 2 - 4 } & FCR & $1.12 \pm 0.03$ & 0.94 \\
\cline { 2 - 4 } & Mortality $(\%)$ & $0.8 \pm 0.1$ & \\
\hline \multirow{5}{*}{ Overall } & FCR & 0.94 & \\
\hline
\end{tabular}

${ }^{\mathrm{a}} \mathrm{FCR}=$ Food fed/gain.

Table 2: Individual fish mean ( \pm SE) total length, weight, specific growth rate $\left(\mathrm{SGR}^{\mathrm{a}}\right)$, and condition factor $\left(\mathrm{K}^{\mathrm{b}}\right)$ of rainbow trout reared with or without exercise.

\begin{tabular}{|l|l|l|l|}
\hline & & Unexercised & Exercised \\
\hline \multirow{4}{*}{ Trial 1 } & Length $(\mathrm{mm})$ & $60 \pm 2$ & $61 \pm 1$ \\
\cline { 2 - 4 } & Weight $(\mathrm{g})$ & $2.5 \pm 0.2$ & $2.7 \pm 0.2$ \\
\cline { 2 - 4 } & SGR & $5.59 \pm 0.19$ & $5.73 \pm 0.16$ \\
\cline { 2 - 4 } & $\mathrm{K}$ & $1.14 \pm 0.05$ & $1.16 \pm 0.01$ \\
\hline \multirow{4}{*}{ Trial 2 } & Length $(\mathrm{mm})$ & $146 \pm 2$ & $143 \pm 2$ \\
\cline { 2 - 4 } & Weight $(\mathrm{g})$ & $38.5 \pm 1.6$ & $37.2 \pm 2.1$ \\
\cline { 2 - 4 } & SGR & $2.81 \pm 0.04$ & $2.70 \pm 0.05$ \\
\cline { 2 - 4 } & $\mathrm{K}$ & $1.24 \pm 0.01$ & $1.26 \pm 0.02$ \\
\hline
\end{tabular}

a $S G R=100 *(\ln$ (end weight $)-\ln$ (start weight) $) /($ number of days $)$. ${ }^{\mathrm{b}} \mathrm{K}=10^{5 *}\left[(\right.$ fish weight $\left.) /(\text { fish length })^{3}\right]$. 


\section{Discussion}

The results of this study indicate that exercise beginning with initial feeding does not improve the growth of rainbow trout during hatchery rearing. This study is unique because it used small rainbow trout, which were only $27 \mathrm{~mm}$ long at the start of the experiment. Most research using exercise in juvenile salmonids begins when the fish are larger. For example, Parker and Barnes [37] found positive effects of exercise in a trial using $72 \mathrm{~mm}$ long rainbow trout. Voorhees et al. [16] conducted an exercise study with $69 \mathrm{~mm}$ rainbow trout and Reiser et al. [11] used rainbow trout that were $409 \mathrm{~mm}$ long. Exercise studies using other salmonid species have also used larger fish, such as the $130 \mathrm{~mm}$ Arctic charr (Salvelinus alpinus) used by Christiansen and Jobling [12].

The lack of difference in growth between the control and exercise regime tanks in this study support the observations of Voorhees et al. [16] that a combination of both physical and occupational enrichment was not necessary to improve the hatchery rearing performance of rainbow trout. Voorhees et al. [16] reported that either exercise or vertically-suspended structures increased trout growth, but that no further improvements were realized when both forms of environmental enrichment were combined. The lack of any improvement in growth observed using exercise in this study was likely due to the presence of vertically-suspended structures in both the exercise and non-exercise tanks.

The water velocities used for exercise in this experiment may have affected the results. At the start of the first trial, the exercise velocities were $5 \mathrm{~cm} \mathrm{~s}^{-1}$, which based on fish size was approximately 3.1 body lengths per second. By the end of the second trial, relative velocities in the exercised fish had decreased to approximately 0.9 body lengths per second. The preferred relative velocity for optimal exercise in salmonids has been reported to be between 1.5 and 2.0 body lengths per second $[6,37,38]$. The relatively high velocities used for exercise at the start of the trial may have been particularly deleterious. Exercising Chinook salmon (Oncorhynchus tshawytscha) at 3.0 body lengths per second resulted in poorer feed conversion ratios compared to those exercised at 1.5 body lengths per second [37].

The feed conversion ratios obtained in this study are consistent with the observations of Huysman et al. [29] and Voorhees et al. [16]. They are also similar to studies using similarly sized rainbow trout in environmental enrichment studies $[15,25,27]$. The decreased feed conversion ratio in the first trial compared to the second trial was likely due to the smaller size of the fish [39].

It is possible that the high rearing densities encountered at the end of the second trial may have influenced trout growth [40-42]. It is possible, as suggested by Huysman et al. [29], that the trout in the exercised tanks initially grew more rapidly, with growth slowing as they achieved relatively high densities faster than the unexercised tanks. In other words, the fish in the control tanks may have grown more slowly throughout the course of the second trial and only achieved the high final densities because of the long duration of the experiment. Interestingly, the final tank densities observed in this study were higher than those reported by Huysman et al. [29].
The specific growth rates of this study are consistent with those of similarly-sized rainbow trout reared using vertically-suspended enrichment $[15,16,29]$. However, Gregory and Wood [7] reported a much lower specific growth rate for juvenile rainbow trout of similar size who were exercised intermittently than was observed in this experiment. The difference may be because of the inclusion of vertically-suspended enrichment, which has been shown to improve specific growth rate [25,27]. It may also be due to differences in fish size, water temperature, water chemistry, diet, or the genetic strain used, though the results are similar to other non-enriched salmonid exercise studies $[7,15,43]$.

In conclusion, the results of this study indicate no significant improvement in the rearing performance of rainbow trout when exercised in the presence of vertically-suspended environmental enrichment. Further research should examine the interaction of exercise routines and vertically-suspended enrichment, including evaluating exercise routines designed to minimize the risk of exercise fatigue.

\section{Acknowledgements}

We thank Lynn Slama, Joshua Caasi, and Michael Robidoux for their assistance with this study.

\section{References}

1. Li XM, Yu LJ, Wang C, Zeng LQ, Cao ZD, et al. (2013) The effect of aerobic exercise training on growth performance, digestive enzyme activities and postprandial metabolic response in juvenile qingbo (Spinibarbus sinensis). Comparative Biochemistry and Physiology Part A: Molecular \& Integrative Physiology 166: 8-16. [crossref]

2. Liu G, Wu Y, Qin X, Shi X, Wang X (2018) The effect of aerobic exercise training on growth performance, innate immune response and disease resistance in juvenile Schizothorax prenanti. Aquaculture 486: 18-25.

3. Martin-Perez M, Fernandez-Borras J, Ibarz A, Millan-Cubillo A, Felip O, et al. (2012) New insights into fish swimming: a proteomic and isotopic approach in gilthead sea bream. Journal of Proteome Research 11: 3533-3547.

4. Shrivastava J, Rašković B, Blust R, De Boeck G (2018) Exercise improves growth, alters physiological performance and gene expression in common carp (Cyprinus carpio). Comparative Biochemistry and Physiology Part A: Molecular \& Integrative Physiology 226: 38-48. [crossref]

5. Gerber B, Stamer A, Stadtlander T (2015) Environmental enrichment and its effects on welfare in fish. Review. Research Institute of Organic Agriculture (FiBL) $\mathrm{CH}-$ Frick.

6. Christiansen JS, Ringø E, Jobling M (1989) Effects of sustained exercise on growth and body composition of first-feeding fry of Arctic charr, Salvelinus alpinus (L.). Aquaculture 79: 329-335.

7. Gregory TR, Wood CM (1998) Individual variation and interrelationships between swimming performance, growth rate, and feeding in juvenile rainbow trout (Oncorhynchus mykiss). Canadian Journal of Fisheries and Aquatic Sciences 55: 1583-1590.

8. Houlihan DF, Laurent P (1987) Effects of exercise training on the performance, growth, and protein turnover of rainbow trout (Salmo gairdneri). Canadian Journal of Fisheries and Aquatic Sciences 44: 1614-1621.

9. Lagasse JP, Leith DA, Romey DB, Dahrens OF (1980) Stamina and survival of Coho salmon reared in rectangular circulating ponds and conventional raceways. The Progressive Fish-Culturist 42: 153-156.

10. Voorhees JM, Barnes ME, Chipps SR, Brown ML (2018) Rearing performance of juvenile brown trout (Salmo trutta) subjected to exercise and dietary bioprocessed soybean meal. Open Journal of Animal Sciences 8: 303-328. 
Benj Morris (2020) Effects of Intermittent Exercise during Initial Rainbow Trout Oncorhynchus mykiss Rearing in Tanks Containing VerticallySuspended Environmental Enrichment

11. Reiser S, Sähn N, Pohlmann DM, Willenberg M, Focken U (2019) Rearing juvenile brown Salmo trutta (L.), and rainbow trout Oncorhynchus mykiss (Walbaum), in earthen ponds with and without an induced current. Journal of Applied Aquaculture 31: 1-21.

12. Christiansen JS, Jobling M (1990) The behaviour and the relationship between food intake and growth of juvenile Arctic charr, Salvelinus alpinus L., subjected to sustained exercise. Canadian Journal of Zoology 68: 2185-2191.

13. Davison W, Goldspink G (1977) The effect of prolonged exercise on the lateral musculature of the brown trout (Salmo trutta). Journal of Experimental Biology 70: $1-12$.

14. Brown EJ, Bruce M, Pether S, Herbert NA (2011) Do swimming fish always grow fast? Investigating the magnitude and physiological basis of exercise-induced growth in juvenile New Zealand yellowtail kingfish, Seriola lalandi. Fish Physiology and Biochemistry 37: 327-336. [crossref]

15. Voorhees JM, Barnes ME, Chipps SR, Brown ML (2019) Effects of Exercise and Bioprocessed Soybean Meal Diets during Rainbow Trout Rearing. The Open Biology Journal 7: 1-13.

16. Voorhees JM, Huysman N, Krebs E, Barnes ME (2020) Use of Exercise and Structure during Rainbow Trout Rearing. Open Journal of Applied Sciences 10: 258-269.

17. Bosakowski T, Wagner EJ (1995) Experimental use of cobble substrates in concrete raceways for improving fin condition of cutthroat (Oncorhynchus clarki) and rainbow trout (O. mykiss). Aquaculture 130: 159-165.

18. Berejikian BA, Tezak EP, Flagg TA, LaRae AL, Kummerow E, et al. (2000) Social dominance, growth, and habitat use of age-0 steelhead (Oncorhynchus mykiss) grown in enriched and conventional hatchery rearing environments. Canadian Journal of Fisheries and Aquatic Sciences 57: 628-636.

19. Berejikian BA (2005) Rearing in enriched hatchery tanks improves dorsal fin quality of juvenile steelhead. North American Journal of Aquaculture 67: 289-293.

20. Näslund J, Rosengren M, Del Villar D, Gansel L, Norrgard JR, et al. (2013) Hatchery tank enrichment affects cortisol levels and shelter-seeking in Atlantic salmon (Salmo salar). Canadian Journal of Fisheries and Aquatic Sciences 70: 585-590.

21. Salvanes AGV, Moberg O, Ebberson LOE, Nilsen TO, Jensen KH et al. (2013) Environmental enrichment promotes neural plasticity and cognitive ability in fish. Proceedings of the Royal Society B 280.

22. Roberts LJ, Taylor J, Gough PJ, Forman DW, Leaniz CG (2014) Silver spoon in the rough: can environmental enrichment improve survival of hatchery Atlantic salmon Salmo salar in the wild? Journal of Fish Biology 85: 1972-1991.

23. Bergendahl IA, Salvanes AGV, Braithwaite VA (2016) Determining the effects of duration and recency of exposure to environmental enrichment. Applied Animal Behaviour Science 176: 163-169.

24. Cogliati KM, Herron CL, Noakes DLG, Schreck CB (2019) Reduced stress response in juvenile Chinook salmon reared with structure. Aquaculture 504: 96-101.

25. Kientz JL, Barnes ME (2016) Structural complexity improves the rearing performance of rainbow trout in circular tanks. North American Journal of Aquaculture 78: 203207.

26. Kientz JL, Crank KM, Barnes ME (2018) Enrichment of circular tanks with vertically suspended strings of colored balls improves rainbow trout rearing performance. North American Journal of Aquaculture 80: 162-167.
27. Krebs E, Huysman N, Voorhees JM, Barnes ME (2018) Suspended arrays improve rainbow trout growth during hatchery rearing in circular tanks. International Journal of Aquaculture and Fishery Sciences 4: 27-30.

28. Crank KM, Kientz JL, Barnes ME (2019) An evaluation of vertically suspended environmental enrichment structures during rainbow trout rearing. North American Journal of Aquaculture 81: 94-100.

29. Huysman N, Krebs E, Voorhees JM, Barnes ME (2019) Use of large verticallysuspended rod array in circular tanks during juvenile rainbow trout rearing. International Journal of Marine Biology and Research 4: 1-5.

30. Huysman N, Krebs E, Voorhees JM, Barnes ME (2019) Use of two vertically-suspended environmental enrichment arrays during rainbow trout rearing in circular tanks. International Journal of Innovative Studies in Aquatic Biology and Fisheries 5: 25-30.

31. Rosburg AJ, Fletcher BL, Barnes ME, Treft CE, Bursell BR (2019) Verticallysuspended environmental enrichment structures improve the growth of juvenile landlocked fall Chinook salmon. International Journal of Innovative Studies in Aquatic Biology and Fisheries 5: 17-24.

32. White SC, Krebs E, Huysman N, Voorhees JM, Barnes ME (2019) Use of suspended plastic conduit arrays during brown trout and rainbow trout rearing in circulars. North American Journal of Aquaculture 81: 101-106.

33. Jones MD, Krebs E, Huysman N, Voorhees JM, Barnes ME (2019) Rearing performance of Atlantic salmon grown in circular tanks with vertically-suspended environmental enrichment. Open Journal of Animal Science 9: 249-257.

34. Walker LM, Parker TM, Barnes ME (2016) Full and partial overhead tank cover improves rainbow trout rearing performance. North American Journal of Aquaculture 78: 20-24.

35. Buterbaugh GL, Willoughby H (1967) A feeding guide for brook, brown, and rainbow trout. The Progressive Fish-Culturist 29: 210-215.

36. American Fisheries Society (AFS) (2014) Guidelines for the Use of Fishes in Research. Bethesda, MD: American Fisheries Society.

37. Parker TM, Barnes ME (2014) Rearing velocity impacts on landlocked fall Chinook salmon (Oncorhynchus tshawytscha) growth, condition, and survival. Open Journal of Animal Sciences 4: 244-252.

38. Parker TM, Barnes ME (2015) Effects of different water velocities on the hatchery rearing performance and recovery from transportation of rainbow trout fed two different rations. Transactions of the American Fisheries Society 144: 882-890.

39. Handeland SO, Imsland AK, Stefansson SO (2008) The effect of temperature and fish size on growth, feed intake, food conversion efficiency and stomach evacuation rate of Atlantic salmon post-smolts. Aquaculture 283: 36-42.

40. Holm JC, Refstie T, Bø S (1990) The effect of fish density and feeding regimes on individual growth rate and mortality in rainbow trout (Oncorhynchus mykiss). Aquaculture 89: 225-232.

41. Procarione LS, Barry TP, Malison JA (1999) Effects of high rearing densities and loading rates on the growth and stress responses of juvenile rainbow trout. North American Jounral of Aquaculture 61: 91-96.

42. Ellis T, North B, Scott AP, Bromage NR, Porter M, et al. (2002) The relationships between stocking density and welfare in farmed rainbow trout. Journal of Fish Biology 61: 493-531.

43. Jørgensen EH, Jobling M (1993) The effects of exercise on growth, food utilisation and osmoregulatory capacity of juvenile Atlantic salmon, Salmo salar. Aquaculture 116: $233-246$.

\section{Citation:}

Benj Morris, Jill M. Voorhees, Nathan Huysman, Eric Krebs and Michael E. Barnes (2020) Effects of Intermittent Exercise during Initial Rainbow Trout Oncorhynchus mykiss Rearing in Tanks Containing Vertically-Suspended Environmental Enrichment. Aquac Fish Stud Volume 2(2): 1-4. 